Volume 1, Number 2, 2015

\title{
Measurement of Roughness of Internal Surface of Measuring Pipeline in Real Time for Standard Orifice Plates
}

\author{
Bohdan Chaban $^{*}$ \\ Lviv Polytechnic National University, 12, S. Bandery St., Lviv, 79013, Ukraine
}

Received: November 25, 2015. Revised: December 08, 2015. Accepted: December 15, 2015.

(C) 2015 The Authors. Published by Lviv Polytechnic National University.

\begin{abstract}
Methods for measuring the roughness of the internal surface of a measuring pipeline for projected rectilinear sections of a measuring pipeline and for rectilinear sections that are in operation have been determined. The new equations for calculating the hydraulic resistance coefficient of friction of natural gas on the internal surface of the measuring pipeline, the average value of natural gas pressure along the section of a measuring pipeline and the equivalent roughness were obtained. These equations provide improvement of accuracy of natural gas flow rate and volume measurement by means of the differential pressure method. The equation for calculating the Reynolds number from the conditions of the roughness measurement in real time was obtained. The technique of selection of methods of the roughness measuring was presented. Functional scheme of process automation of measurement the equivalent roughness of the internal surface of the measuring pipeline was developed.
\end{abstract}

Keywords: differential pressure method; roughness; flow; natural gas; standard orifice plate; hydraulic resistance coefficient of friction; Reynolds number.

\section{Introduction}

The rising cost of fluid energy resources, which include natural gas, limiting their reserves, and the need of energy resources imports from other countries raised the question of its economical consumption and efficient use. These requirements can be met only on the condition of accurate natural gas accounting at all stages of its transportation and delivery to the consumers. The most common method for measuring flow rate and volume of natural gas is the differential pressure method. The main provisions for this method are described in the national standard of Ukraine DSTU GOST 8.586.1:2009 [1] and in the international standard ISO 5167-1: 2003 [2]. One way to improve the accuracy of the result of measurement of flow rate and volume of natural gas is application of advanced analytical dependences for calculating the coefficients of equation of natural gas flow rate and the accuracy of measurement values of input variables in real time. Input variables which measure in real time are also equivalent roughness of the internal surface of the measuring pipeline $R_{U}$ and the value of the arithmetical mean deviation of the roughness profile $R_{a}$.

When measuring flow rate and volume of natural gas, standard orifice plate (SOP) are most commonly used, its technical requirements are described in [3, 4]. According to ISO 5167-2: 2003 [4] orifice plate can be used in limited ranges of minimum and maximum relative roughness value, beyond which it is impossible to apply the differential pressure method.

Application of DSTU GOST 8.586.2:2009 [3] orifice plate also can be used for the relative roughness ranges that go beyond these limits, but it is necessary to consider correction factor $K_{U H}$, that takes into account the roughness of the internal surface of a measuring pipeline. Correction factor $K_{U}$ enters the equation of natural gas flow rate and depends on the equivalent roughness $R_{U}$.

\footnotetext{
"Corresponding author. Email address: b.chaban.91@gmail.com
} 
Therefore, increase in the accuracy of measurement of the equivalent roughness of the internal surface of the measuring pipeline or the value of the arithmetical mean deviation of the roughness profile in real time is an important task.

\section{Method of roughness measurement}

To determine the roughness of the internal surface of the measuring pipeline two methods are used:

- The method of direct measurement of the roughness of the internal surface of the measuring pipeline, which is used at manufacturing rectilinear sections of the measuring pipeline;

- The method of indirect measurement of the roughness of the internal surface of the measuring pipeline (for rectilinear sections of a measuring pipeline that are in operation).

The method of direct measurement of the roughness of the internal surface of the measuring pipeline is carried out by means profilometers and profilografs which measure the value of the arithmetical mean deviation of the roughness profile $R_{a}$. By the value of $R_{a}$ the value of $R_{\amalg}$ can be calculated by the formula [5]

$$
R_{\amalg}=\pi \cdot R_{a} .
$$

According to DSTU GOST 8.586.1:2009 [1], the roughness of the internal surface of the measuring pipeline is measured at the same sections of pipeline that are used for definition and verification of the internal diameter of the measuring pipeline $D$ at the operating temperature of natural gas, at least three cross-sections of the pipeline, equally distributed on the interval $0,5 \cdot D$, two of which sections correspond to distances $0 \cdot D$ and $0,5 \cdot D$ from the place of holes for weaning pressure, located to orifice plate. But we do not know the value of the roughness along all the distance $10 \cdot D[3]$ to the standard orifice plate. Another disadvantage of this method is that the roughness of the internal surface of the measuring pipeline changes during operation.

Measurement of the equivalent roughness of the internal surface of the measuring pipeline should be carried at a distance $l$ upstream of the inlet face of a standard orifice plate:

- If the distance $L$ from the first fitting to the inlet face of a standard orifice plate is larger than $10 \cdot D$, then according to DSTU GOST 8.586.1:2009 [1]

$$
l=10 \cdot D ;
$$

- If the distance $L$ from the first local resistance to the inlet face of a standard orifice plate is less than $10 \cdot D$, then according to DSTU GOST 8.586.2:2009 [3]

$$
l=L(\beta),
$$

where $\beta$ is the diameter ratio of the standard orifice plate. The value of $L$ is selected from the standard DSTU GOST 8.586.2:2009 [3] or ISO 5167-2: 2003 [4] depending on the diameter ratio of the orifice plate opening $\beta$ for each type of fitting.

Therefore the method of direct measurement does not provide accurate values of equivalent roughness $R_{U I}$ when measuring it on rectilinear sections of a measuring pipeline that are in operation.

After the research we propose to define the equivalent roughness of the internal surface of the measuring pipeline by means of an indirect measurement.

In this case, it is determined by Colebrook-White equation through measured value of hydraulic resistance coefficient $\lambda$ of friction of natural gas on the internal surface of the measuring pipeline [6]

$$
R_{U}=\left(3.71 \cdot 10^{-\frac{1}{2 \cdot \sqrt{\lambda}}}-\frac{9.34}{\mathrm{Re} \cdot \sqrt{\lambda}}\right) \cdot D,
$$

where Re is the Reynolds number. 
The article aims:

- to obtain the equations for calculating the hydraulic resistance coefficient of friction of natural gas on the internal surface of the measuring pipeline, the average value of natural gas pressure along the section of a measuring pipeline and the equivalent roughness of the internal surface of the measuring pipeline;

- to obtain the equation for calculating the Reynolds number from the conditions of measurement the roughness in real time;

- to develop the technique of selection of methods of measuring the roughness of the internal surface of a measuring pipeline;

- to develop the functional scheme of process automation of measurement the equivalent roughness of the internal surface of the measuring pipeline.

\section{Definition of roughness based on its measurement in real time}

Hydraulic resistance coefficient $\lambda$ of friction of natural gas on the internal surface of the measuring pipeline can be defined from the system of the differential equations of motion of natural gas. This system of equations is formed of the law of conservation of stream energy of natural gas, the equation of the law of conservation of stream mass of natural gas and natural gas equation of state $[7,8]$

$$
\left\{\begin{array}{c}
\frac{d p}{\rho}+\frac{\lambda}{D} \cdot \frac{v^{2}}{2} d x=0 \\
\frac{d m}{d \tau}=q_{m}=\rho v F=\text { const } \\
p=\rho \cdot z \cdot \frac{R}{M} \cdot T
\end{array}\right.
$$

where $d p$ is the change of the pressure of natural gas along the length of the straight section $l$ upstream of the standard orifice plate; $\rho$ is the density of natural gas; $v$ is the linear velocity of natural gas in the measuring pipeline; $d x$ is the elementary section of the pipeline; $d m$ the change in mass of natural gas for the period of time $d \tau ; q_{m}$ is the mass flow rate of natural gas; $F$ is the cross sectional area of the measuring pipeline; $z$ is the compression factor; $R$ is the universal gas constant $(R=8.31451 \mathrm{~kJ} / \mathrm{mol} \cdot \mathrm{K}) ; M$ is the molar mass of natural gas; $T$ is the temperature of natural gas in the measuring pipeline.

Let us reduce the system of equations (5) to one differential equation of natural gas pressure distribution in the horizontal measuring pipeline

$$
p d p+\frac{\lambda \cdot q_{m}^{2} \cdot z \cdot R \cdot T}{2 \cdot D \cdot M \cdot F^{2}} d x=0 .
$$

Now we shall integrate equation (6) over the pressure and over the length of the measuring pipeline

$$
\int_{p_{1}}^{p_{2}} p d p+\frac{\lambda \cdot q_{m}^{2} \cdot z \cdot R \cdot T}{2 \cdot D \cdot M \cdot F^{2}} \int_{0}^{l} d x=0,
$$

where $p_{l}$ is the natural gas pressure at a distance $l$ from the standard orifice plate; $p_{2}$ is the natural gas pressure at the inlet face of a standard orifice plate. Natural gas pressure at a distance $l$ from the standard orifice plate is determined by measuring the pressure of natural gas at the inlet face of a standard orifice plate and the pressure loss $\Delta p_{l}$ between the inlet face of a standard orifice plate and at a distance $l$ from the standard orifice plate that arise due to friction of natural gas on the wall of the measuring pipeline,

$$
p_{1}=p_{2}+\Delta p_{l}
$$


As a result of integration we obtain the following equation

$$
p_{2}^{2}-p_{1}^{2}+\frac{\lambda \cdot q_{m}^{2} \cdot z \cdot R \cdot T}{D \cdot M \cdot F^{2}} \cdot l=0
$$

From equation (9) we obtain the expression for definition of hydraulic resistance coefficient of friction of natural gas

$$
\lambda=\frac{\left(p_{1}^{2}-p_{2}^{2}\right) \cdot D \cdot M \cdot F^{2}}{q_{m}^{2} \cdot z \cdot R \cdot T \cdot l} .
$$

Mass flow rate $q_{m}$ of natural gas is determined by the equation

$$
q_{m}=\frac{\pi \cdot \operatorname{Re} \cdot \mu \cdot D}{4}
$$

Substituting equations (8) and (11) in equation (10) and taking into account the equation of state of natural gas (5), we obtain the equation for determining the hydraulic resistance coefficient of friction of natural gas

$$
\lambda=\frac{\Delta p_{l} \cdot\left(2 \cdot p_{2}+\Delta p_{l}\right) \cdot \rho_{c p} \cdot D^{3}}{p_{c p} \cdot R e^{2} \cdot \mu_{c p}^{2} \cdot l}
$$

where $p_{c p}$ is the average value of pressure along the pipeline section between the points of selection of pressure values $p_{2}$ and $p_{1} ; \rho_{c p}, \mu_{c p}$ - respectively the average value of density of natural gas and natural gas dynamic viscosity along the pipeline section between the points of selection of pressure values $p_{2}$ and $p_{1}$.

We obtained the equation for calculating the average value of natural gas pressure along the section $l$

$$
p_{c p}=\frac{2}{3} \cdot \frac{3 \cdot p_{2} \cdot\left(p_{2}+\Delta p_{l}\right)+\Delta p_{l}^{2}}{2 \cdot p_{2}+\Delta p_{l}}
$$

Substituting equation (12) in equation (4) we obtain the equation for determining the equivalent roughness of the internal surface of the measuring pipeline

$$
R_{U}=3.71 \cdot D \cdot 10^{-\frac{R e \cdot \mu_{c p}}{2 \cdot} \sqrt{\frac{p_{c p} \cdot l}{\Delta p_{l} \cdot\left(2 \cdot p_{2}+\Delta p_{l}\right) \cdot \rho_{c p} \cdot D^{3}}}}-9.34 \cdot \mu_{c p} \cdot \sqrt{\frac{p_{c p} \cdot l}{\Delta p_{l} \cdot\left(2 \cdot p_{2}+\Delta p_{l}\right) \cdot \rho_{c p} \cdot D}} .
$$

4. Technique of selection of methods of measuring the roughness of the internal surface of a measuring pipeline From equation (14) we determine the Reynolds number

$$
\operatorname{Re}=-\frac{2}{\mu_{c p}} \sqrt{\frac{\Delta p_{l} \cdot\left(2 \cdot p_{2}+\Delta p_{l}\right) \cdot \rho_{c p} \cdot D^{3}}{p_{c p} \cdot l}} \cdot \lg \left(\frac{R_{U}}{3.71 \cdot D}+2.52 \cdot \mu_{c p} \cdot \sqrt{\frac{p_{c p} \cdot l}{\Delta p_{l} \cdot\left(2 \cdot p_{2}+\Delta p_{l}\right) \cdot \rho_{c p} \cdot D^{3}}}\right) .
$$

If the calculated value of Reynolds number is less than the acceptable minimum of Reynolds number $\mathrm{Re}_{\min }$, equation for determining which is given in $[3,4]$, the definition of equivalent roughness of the internal surface of a measuring pipeline is made by the method of direct measurement, which is used at manufacturing of rectilinear sections of the measuring pipeline. The value of the acceptable minimum of Reynolds number $\mathrm{Re}_{\min }$ calculated from equation [3]:

- For orifice plate with corner pressure tappings or three radius pressure tappings

$$
\operatorname{Re}_{\min }=\left\{\begin{array}{c}
5000 \text { if } \beta \leq 0,56 \\
16000 \cdot \beta^{2} \text { if } \beta>0,56
\end{array}\right. \text {. }
$$


- For orifice plate with flange pressure tappings

$$
\operatorname{Re}_{\min }=\max \left(5000 ; 1.7 \cdot 10^{5} \cdot \beta^{2} \cdot D\right) .
$$

If the calculateded value of Reynolds number is less than the acceptable minimum of Reynolds number $\mathrm{Re}_{\min }$ $[3,4]$, the value of equivalent roughness of the internal surface of a measuring pipeline is measured by indirect method in real time by the equation (14).

\section{Development of the functional scheme of process automation of measurement the equivalent roughness of the internal surface of the measuring pipeline}

Based on the provisions set out in 2-4, the functional scheme of process automation of measurement the equivalent roughness of the internal surface of the measuring pipeline in real time was developed (see Fig. 1).

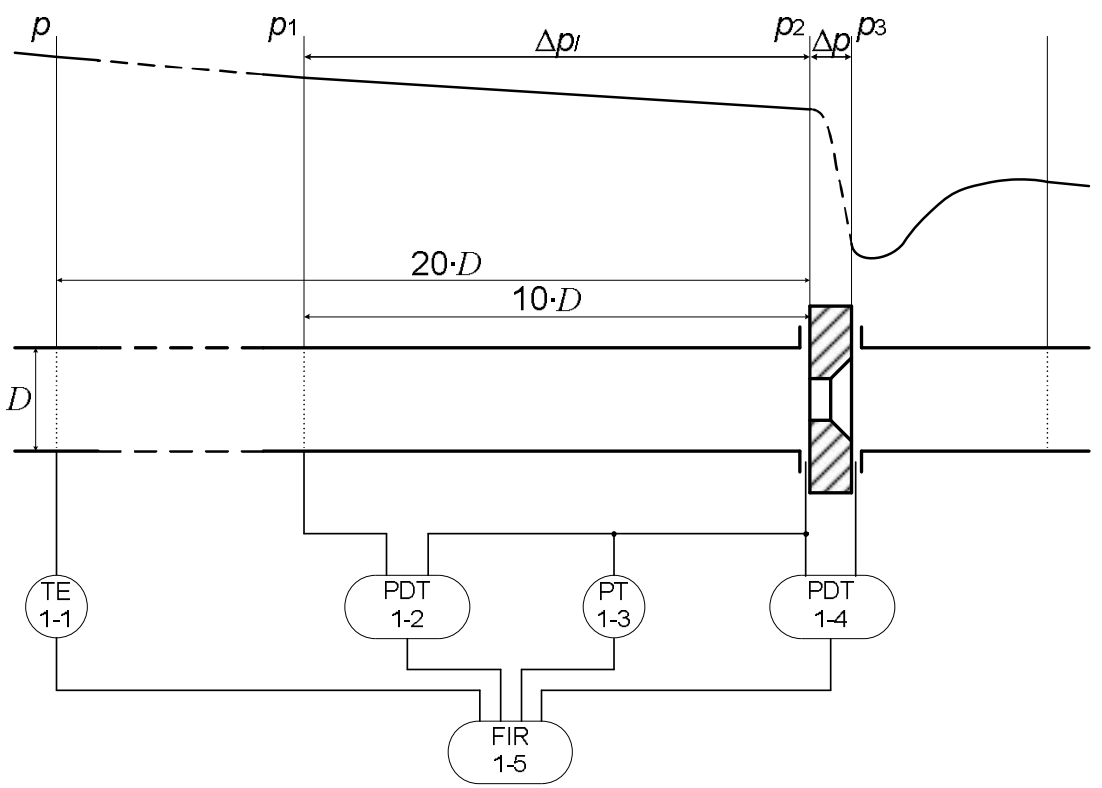

Fig. 1. Functional scheme of process automation of measurement the equivalent roughness of the internal surface of the measuring pipeline in real time, where TE is temperature sensor;

PT is pressure sensor; PDS is differential pressure sensor; FIR is calculator of natural gas flow rate and volume

The functional scheme of process automation consists of sensors that measure:

- Natural gas temperature in measuring pipeline on the distance $20 \cdot D$ to standard orifice plate (pos. 1-1, Fig. 1);

- Differential pressure on the rectilinear section of the measuring pipeline, which has a length $10 \cdot D($ pos. $1-2)$;

- Natural gas pressure (pos. 1-3);

- Differential pressure on the standard orifice plate (pos. 1-4).

The signals from the sensors are fed to the calculator of natural gas flow rate and volume (pos. 1-5), which calculates natural gas flow rate and volume, taking into account the equivalent roughness of the internal surface of the measuring pipeline, as measured by indirect method.

\section{Conclusion}

The existing methods of measurement of the roughness of the internal surface of the measuring pipeline are analyzed in this paper.

New analytical dependencies for calculating the hydraulic resistance coefficient of friction of natural gas on the internal surface of the measuring pipeline, the average value of natural gas pressure along the section of a measuring pipeline and the equivalent roughness of the internal surface of the measuring pipeline in real time are obtained. 
The equation for calculating the Reynolds number from the conditions of measurement the roughness in real time is obtained.

The technique of selection of methods of measuring the roughness of the internal surface of a measuring pipeline is presented. Functional scheme of process automation of measurement the equivalent roughness of the internal surface of the measuring pipeline is developed.

\title{
References
}

[1] Metrology. Measurements of liquid and gas flow rate and quantity by means of orifice instruments. Part 1. Principle method of the of measurements general requirements: DSTU GOST 8.586.1:2009. - Kyiv (Ukraine) : Derzhspozhyvstandart Ukrainy (DSTU), 2010. 98 pages. (National standard). (in Ukrainian)

[2] Measurement of fluid flow by means of pressure differential devices inserted in circular cross-section conduits running full - Part 1: General principles and requirements: ISO 5167-1:2003. - Geneva (Switzerland): International Organization for Standardization (ISO), 2007. 40 pages. (International standard).

[3] Metrology. Measurements of liquid and gas flow rate and quantity by means of orifice instruments. Part 2. Orifice plates. Technical requirements: DSTU GOST 8.586.2:2009. - Kyiv (Ukraine) : Derzhspozhyvstandart Ukrainy (DSTU), $2010 .-98$ pages. (National standard). (in Ukrainian)

[4] Measurement of fluid flow by means of pressure differential devices inserted in circular cross-section conduits running full - Part 2: Orifice plates: ISO 5167-2:2003. - Geneva (Switzerland): International Organization for Standardization (ISO), 2007. - 54 pages. (International standard).

[5] Idelchik I. Handbook of hydraulic resistance / ed. by M. O. Steinberg. - Moscow : Mashynostroenie Publishing House, 1992 . - 672 p. (in Russian).

[6] Measurement of fluid flow with primary devices; orifice plates and nozzles for special applications: VDI 2040, Blat 1. 1971. - New York (United States): American National Standarts Institute (ANSI), 1972. (Foreign standard).

[7] Abramovich H. Applied gas dynamics / H. Abramovich. - Moscow : Nauka Publishing House, 1969. - 824 p. (in Russian).

[8] L. Lesovoy, L. Blyznyak, "Comparative analysis of the distribution of natural gas pressure in inclined and horizontal pipelines", Proc. of Lviv Polytechnic National University: Heat Power Engineering. Environmental Engineering. Automation, No. 460, 2002, pp. 56-60 (in Ukrainian).

\section{Вимірювання шорсткості внутрішньої поверхні вимірювального трубопроводу в реальному часі для стандартних діафрагм}

\author{
Богдан Чабан \\ Національний університет "Львівська політехніка", вул. С. Бандери, 12, Львів, 79013, Украӥна
}

\section{Анотація}

Визначені методи вимірювання шорсткості внутрішньої поверхні вимірювального трубопроводу для прямолінійних ділянок вимірювального трубопроводу, які проектуються, і для прямолінійних ділянок, які знаходяться в експлуатації. Отримано нові рівняння для визначення коефіцієнта гідравлічного опору тертя природного газу об внутрішню поверхню вимірювального трубопроводу, середнього значення тиску природного газу на довжині вимірювального трубопроводу та еквівалентної шорсткості в реальному часі. Ці рівняння дають можливість підвищити точність вимірювання витрати та кількості природного газу методом змінного перепаду тиску. Отримано рівняння для визначення числа Рейнольдса 3 умови вимірювання шорсткості в реальному часі. Наведена методика вибору методу вимірювання шорсткості. Розроблено функціональну схему автоматизації вимірювання еквівалентної шорсткості внутрішньої поверхні вимірювального трубопроводу.

Ключові слова: метод змінного перепаду тиску; шорсткість; витрата; природний газ; стандартна діафрагма; коефіцієнт гідравлічного опору тертя; число Рейнольдса. 